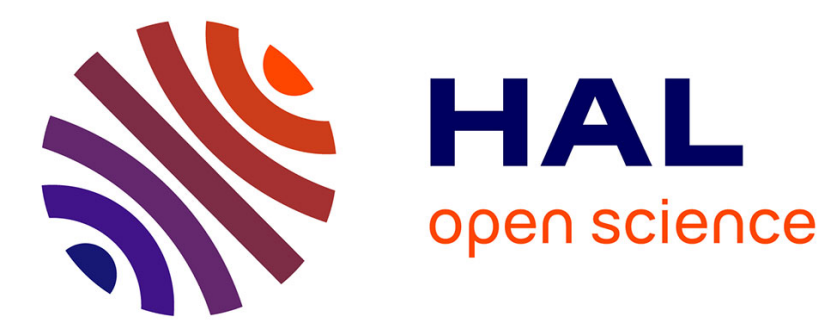

\title{
Determinants of Amazon Deforestation: The role of Off-Farm Income
}

\author{
Claudio Araujo, Jean-Louis Combes, José Gustavo Feres
}

\section{To cite this version:}

Claudio Araujo, Jean-Louis Combes, José Gustavo Feres. Determinants of Amazon Deforestation: The role of Off-Farm Income. 2014. halshs-01084611

\section{HAL Id: halshs-01084611 https://shs.hal.science/halshs-01084611}

Preprint submitted on 19 Nov 2014

HAL is a multi-disciplinary open access archive for the deposit and dissemination of scientific research documents, whether they are published or not. The documents may come from teaching and research institutions in France or abroad, or from public or private research centers.
L'archive ouverte pluridisciplinaire HAL, est destinée au dépôt et à la diffusion de documents scientifiques de niveau recherche, publiés ou non, émanant des établissements d'enseignement et de recherche français ou étrangers, des laboratoires publics ou privés. 


\title{
SERIE ETUDES ET DOCUMENTS DU CERDI
}

\section{Determinants of Amazon Deforestation: \\ The role of Off-Farm Income}

\author{
Claudio Araujo \\ Jean-Louis Combes \\ Jose Gustavo Feres
}

Etudes et Documents $\mathrm{n}^{\circ} 23$

October 2014

To quote this document:

Araujo C., J.-L. Combes and J.G. Feres (2014). “Determinants of Amazon deforestation: The role of Off-Farm income", Etudes et Documents, $n^{\circ} 23$, CERDI.

http://cerdi.org/production/show/id/1626/type production id/1

\section{CERDI}

65 BD. F. MITTERRAND

63000 CLERMONT FERRAND - FRANCE

TEL. 0473177400

FAX 0473177428

www.cerdi.org 


\section{The authors}

Claudio Araujo

Associate Professor

Clermont Université, Université d'Auvergne, CNRS, UMR 6587, CERDI, F-63009 Clermont Fd.

Email : claudio.araujo@udamail.fr

Jean-Louis Combes

Professor

Clermont Université, Université d'Auvergne, CNRS, UMR 6587, CERDI, F-63009 Clermont Fd.

Email : J-Louis.COMBES@udamail.fr

Jose Gustavo Feres

Research

Instituto de Pesquisa Econômica Aplicada (IPEA), Av. Presidente Antônio Carlos, 51, 20020-

010, Rio de Janeiro, Brazil

Email : jose.feres@ipea.gov.brBrasil

Corresponding author: Claudio Araujo

La série des Etudes et Documents du CERDI est consultable sur le site :

http://www.cerdi.org/ed

Directeur de la publication : Vianney Dequiedt

Directeur de la rédaction : Catherine Araujo Bonjean

Responsable d'édition : Chantal Brige-Ukpong

ISSN : 2114 - 7957

\section{Avertissement :}

Les commentaires et analyses développés n'engagent que leurs auteurs qui restent seuls responsables des erreurs et insuffisances. 


\begin{abstract}
This paper aims at assessing the determinants of Amazon deforestation, with an emphasis on the role played by off-farm income. We first present a microeconomic model which relates off-farm income to deforestation patterns. We then test the empirical implications by using data on the 2006 Brazilian Agricultural Census. Our results suggest that an increase in off-farm income tends to reduce deforestation. This may be explained by the fact that greater off-farm opportunities tends to increase the opportunity cost of farm labor. Results also show that smallholders are less responsive to the increase in the returns of off-farm activities than large ones, which is in line with our hypothesis of labor market imperfections regarding off-farm activities.
\end{abstract}

Key words: deforestation, farm household, off-farm income, pseudo-panel

JEL codes: Q12, Q23, C23 


\section{Introduction}

Amazon deforestation has been a major issue in the Brazilian environmental agenda, driven by concerns about biodiversity loss and the deterioration of ecosystem services, including the fact that deforestation across the country represents three quarters of the nation's total greenhouse gas emissions (GHG). Curbing deforestation rates is Brazil's most cost-effective emissions reduction mechanism. Forest loss may also put at risk local communities whose livelihoods depend upon the extraction of timber and non-timber resources. Understanding the determinants of deforestation is of paramount importance for the design and implementation of effective policy measures for forest conservation.

There is a large literature on the determinants of Amazon deforestation, and several deforestation drivers have been identified. Empirical studies have pointed out the significant role played by agricultural activities (Barona et al., 2010; Chomitz and Thomas, 2003), land settlement, governmental programs, road infrastructure (Andrade et al., 2013; Pfaff, 1999) and land tenure insecurity (Araujo et al., 2009). However, there are important economic issues which have been neglected. In particular, one may cite the relation between off-farm income and deforestation.

According to Bluffstone (1995), higher off-farm income vis-à-vis revenues associated to agricultural activities may increase the opportunity cost of the latter, reducing the deforestation pressure. In this sense, public policies aimed at stimulating off-farm employment and revenue generation could succeed in curbing deforestation.

Additionally, labor market imperfections regarding off-farm activities may have significant impacts on deforestation (Bluffstone, 1995; Shively and Pagiola, 2004; Groom et al., 2010). Farmers that face restricted access to off-farm labor markets may allocate their time between farm and off-farm activities in an inefficient way. This could be the case, for example, of smallholders that produce mainly for subsistence purposes. The need to assure a minimum production level may lead to an excessive allocation of time to farm activities, resulting in increasing deforestation pressure. In this way, restricted access to off-farm labor markets not only could reduce income generation opportunities in rural areas, but it could also imply in environmental externalities associated to increasing deforestation.

Production for subsistence purposes is still an important activity in the Brazilian rural sector. According to the 2006 Agricultural Census, $72.2 \%$ of the rural establishments declared to allocate part of their production to self-consumption. More importantly, $18 \%$ of the establishments reported that more than $90 \%$ of their total production is destined to self-consumption. Production for subsistence purposes is particularly important in small farms with less than 5 hectares (Grisa et al., 2014). In addition to highlight the role played by production for subsistence purposes, the Agriculture Census also provides some evidence that access to off-farm labor markets varies according to farmsize: while $32 \%$ of the rural establishments with less than 5 hectares declared to have received revenues from off-farm activities, this percentage reaches $52 \%$ among establishments with total area ranging from 100 to 500 ha, rising up to $61 \%$ among those establishments with more than 2,500 ha (IBGE, 2009). 
This article aims at assessing the determinants of deforestation in the Legal Amazon, with an emphasis on the role played by off-farm income. We specify a theoretical model and then test the empirical implications by using data on the 2006 Brazilian Agricultural Census.

Estimation results suggest that an increase in off-farm income may reduce deforestation rates. In fact, higher off-farm incomes could increase the opportunity cost associated to farm activities. The latter become less attractive and farmers dedicate less time to farm activities, therefore reducing deforestation pressure. Results also show that smallholders are less responsive to the increase in the returns of off-farm activities than large ones, which is in line with our hypothesis of labor market imperfections regarding off-farm activities.

The article is organized in five sections. Following this introduction, the second section presents a survey of the empirical literature on the determinants of Amazon deforestation. The third section describes the theoretical model which addresses the relation between off-farm income and deforestation, as well as the consequences of off-farm labor market imperfections on farmers' decisions. The fourth section presents the estimation results. Finally, the concluding section synthetizes the main results and discusses some policy implications.

\section{Literature review}

There is a vast literature on the economic determinants of deforestation. ${ }^{1}$ In this survey, we follow the taxonomy proposed by Angelsen and Kaimowitz (1999), which classify deforestation drivers in two groups: underlying factors and immediate causes.

The so-called underlying factors are related to macroeconomic and policy-related issues that may have an indirect influence on agents' decisions regarding deforestation. Underlying factors include demographic pressure, economic growth, land settlement, governmental programs and regional-oriented development policies. On the other hand, immediate causes are associated to market, technological, institutional and infrastructure conditions that may have a direct influence on agents' decisions regarding deforestation. Immediate causes include the price of agricultural and forestry products, input prices, credit market access, farm and off-farm income, technological progress, transport infrastructure and property rights.

In what follows, we present the main empirical results regarding the influence of underlying factors and immediate causes on Amazon deforestation.

\subsection{Underlying factors}

It is difficult to establish causal connections between underlying factors and deforestation. The transmission mechanisms through which macroeconomic conditions and policy instruments may influence deforestation decisions are difficult to establish, preventing the

\footnotetext{
${ }^{1}$ This section presents the empirical results related to Amazon deforestation. For a broader analysis, see Angelsen and Kaimowitz (1999) or Barbier and Burgess (2001).
} 
identification of causal relations. Such difficulty may be illustrated by the relation between demographic growth and deforestation. Population growth tends to increase the demand for agricultural products, which leads to higher returns in agricultural activities. The higher returns on agricultural activities tend to increase the deforestation pressure. However, population growth is a potentially endogenous variable in deforestation models. Several studies suggest that population growth in forest regions is induced by road construction, land settlement programs and fiscal subsidies. So, deforestation pressures should be attributed to the infrastructure and governmental policies, and not to demographic growth. Actually, Pfaff (1999) observes that population density is not statistically significant in deforestation models that control for infrastructure and institutional characteristics.

The relation between economic growth and deforestation is also quite complex. On the one side, higher economic growth may increase the demand for agricultural products, providing incentives for additional deforestation due to agricultural expansion. On the other hand, higher economic growth is associated to an increase in off-farm income and employment opportunities, thus reducing the pressure on deforestation. Andersen and Reis (1997) and Reis and Blanco (2000) observe that economic growth has a positive impact on deforestation. Nepstad et al. (2009) suggest that the recent slowdown in Amazon deforestation is related to the global financial crisis. However, the empirical models do not include variables related to off-farm income. It should also be remarked that the causality between economic growth and deforestation may be inverted: the exploitation of forest resources may determine economic growth. In this sense, econometric models assessing the relationship between economic growth and deforestation should take into account potential endogeneity problems related to reverse causality.

Regarding public policies, empirical studies suggest that policy measures implemented by the Brazilian government during 1960-1980 have contributed to Amazon deforestation. During this period, the government promoted the occupation of the Amazon territory based on land settlement projects, subsidized credit for agricultural activities and road construction. Andersen and Reis (1997) estimate that this regional development strategy had a positive impact of USD 4.5 billion in the regional GDP. On the other hand, such policies have provided a decisive contribution to Amazon deforestation.

\section{$2.2 \quad$ Immediate causes}

There is substantial empirical evidence on the influence of agricultural product prices on deforestation. Higher profitability in agricultural activities induces the expansion of the agricultural frontier and therefore contributes to the deforestation process. In the Amazon case, Margulis (2003) identifies the high economic returns on cattle ranching activities as the major deforestation driver. By contrast, Ferraz (2001) does not find a significant statistical relationship between agricultural product prices and deforestation. This result may be explained by the geo-ecological barriers to agricultural practices in the Amazon region. In fact, the region is characterized by precipitation levels above 2,000 $\mathrm{mm} /$ year. Such high precipitation levels have a negative impact on the agricultural productivity of several crops.

On the input side, land prices may have a dubious role in the deforestation process. Higher 
land prices may reduce the demand for land, therefore reducing deforestation pressure. Rising land prices may also provide incentives for cattle ranching intensification, thus decreasing new clearing of forest for ranching. On the other hand, higher land prices also mean higher expected returns to the deforestation agents, resulting in increasing deforestation due to speculative reasons. In the Amazon case, Andersen and Reis (1997) and Ferraz (2001) find a negative relation between land prices and deforestation, suggesting that higher land prices may reduce deforestation rates.

Higher farm wages tend to increase the cost of agricultural activities and therefore to reduce deforestation rates. In the same way, higher off-farm income would turn farm activities less attractive, contributing to a reduction in deforestation rates. Ferraz (2001) is the only work that addresses the relation between rural wages and deforestation. The author does not find a statistical significant relation between the two variables. However, it is worth noting that any work has analyzed the question of off-farm income, the subject of the present paper.

In relation to infrastructure, the construction of new roads tends to reduce transport costs. Lower transport costs increases agricultural profitability. In this sense, one expects a positive relation between road density and deforestation. Such relation is verified to the Amazon context by Andersen and Reis (1997), Pfaff (1999) and Ferraz (2001).

Finally, regarding institutional features, poor enforcement of property rights is also an important determinant of deforestation. In the Amazon region, where a large number of farmers do not have land titles, deforestation may act as a signal that the land is allocated to productive purposes. Deforestation as a signal of land use is a strategy adopted by farmers to reduce expropriation risk, since forest areas may be seen as "unproductive land" and therefore subject to expropriation and inclusion in the land reform program. Araujo et al. (2009) analyze the impact of land tenure insecurity in the Amazon region. The authors do not reject the hypothesis that the precarious property rights are associated to higher deforestation rates.

\section{Economic model}

This section presents the theoretical model which addresses the relation between off-farm income and deforestation. The model is based on Groom et al. (2010). For expositional purposes, we first analyze farmers' behavior in a framework without labor market imperfections. Next, we consider labor market imperfections by introducing restrictions on access to off-farm activities.

\subsection{Basic model}

We consider a rural household whose preferences are defined by the revenue level $y$, time allocated to leisure and a vector of consumption determinants $z^{c}$. The household decides to allocate the time $T$ among three activities: leisure $\left(l^{z}\right)$, farm labor $\left(l^{o n}\right)$ and off-farm labor $\left(l^{\text {off }}\right)$, such that $T=l^{z}+l^{o n}+l^{\text {off }}$. We assume that off-farm wage is exogeneous and denoted by $w^{o f f}$. 
The rural household has a total land endowment denoted by $N$. Agricultural production is determined by the amount of land and farm labor, and it may be represented by the production function $q\left(l^{o n}, n\right)$, where $q$ is the production quantity, $l^{o n}$ the quantity of labor allocated to farm activities and $n$ the land allocated to agricultural production. The production technology follows the standard assumptions adopted by the literature: $q_{1}\left(l^{o n}, n\right)>0, q_{2}\left(l^{o n}, n\right)>0, q_{11}\left(l^{o n}, n\right)<0$ and $q_{22}\left(l^{o n}, n\right)<0$, where index $i$ refers to the partial derivative with respect to the $i$-th argument of the function. ${ }^{2}$ We also consider that land and farm labor are complementary inputs: $q_{12}\left(l^{o n}, n\right)>0$. This last hypothesis is supported by empirical estimates of Brazilian agricultural production function parameters (Gomes and Rosado, 2005; Conte and Ferreira Filho, 2007).

The rural household utility function $\mathrm{U}\left(y, l^{z}, c\right)$ is concave and twice differentiable. Total household income is given by the sum of farm agricultural revenue and off-farm income, and it may be represented by $y=p \cdot q\left(l^{o n}, n\right)+w^{o f f} l^{\text {off }}$. The time allocated to leisure is expressed by $l^{z}=T-l^{o n}-l^{\text {off }}$. The optimization problem faced by the rural household may be expressed by

$$
\begin{aligned}
\underset{l^{o n}, l^{o f f}, n}{\operatorname{Max}} & =U\left[p q\left(l^{o n}, n\right)+w^{o f f} l^{o f f}, T-l^{o n}-l^{o f f}, c\right] \\
& \text { such that }
\end{aligned}
$$

$$
\begin{aligned}
& n \leq N ; \\
& l^{o n} \geq 0 ; \\
& l^{o f f} \geq 0
\end{aligned}
$$

We consider the case where rural households allocate time for both farm and off-farm activities. ${ }^{3}$ In this case, the first order conditions of the optimization problem (1) are given by the following expressions:

$$
\begin{gathered}
U_{1(.)} w^{o f f}-U_{2(.)}=0 \\
U_{1(.)} p q_{1(.)}-U_{2(.)}=0 \\
U_{1(.)} p q_{2(.)}+\lambda^{n}=0 \\
\lambda^{n}(N-n)=0, \lambda^{n} \geq 0,(N-n) \geq 0
\end{gathered}
$$

where $\mathrm{U}_{1(.)}$ is the marginal utility of the revenue, $\mathrm{U}_{2(.)}$ is the marginal utility of leisure and $\lambda^{\mathrm{n}}$ is the Lagrangean multiplier associated to the land restriction. If the farmer does not use all available land, the first order conditions may be written as

$$
U_{1(.)} w^{o f f}-U_{2(.)}=0
$$

\footnotetext{
${ }^{2}$ In other words, $q_{1}=\frac{\partial q\left(l^{o n}, n\right)}{\partial l^{o n}}, q_{2}=\frac{\partial q\left(l^{o n}, n\right)}{\partial n}, q_{11}=\frac{\partial^{2} q\left(l^{o n}, n\right)}{\partial l^{o n^{2}}}$ and $q_{22}=\frac{\partial^{2} q\left(l^{o n}, n\right)}{\partial n^{2}}$

${ }^{3} \mathrm{We}$ assume that farm and off-farm activities are divisible. This is not a restrictive hypothesis, since our empirical application deals with aggregated data.
} 


$$
\begin{gathered}
U_{1(.)} p q_{1(.)}-U_{2(.)}=0 \\
p q_{2(.)}=0
\end{gathered}
$$

From conditions (6) and (7), one may verify that

$$
w^{o f f}=p q_{i}\left(l^{o n}, n^{*}\right)
$$

where $\mathrm{n}^{*}$ is the optimal quantity of land allocated to agricultural activities. Condition (9) indicates that the rural household will choose to use farmland such that the marginal productivity of farm activities is equal to the wage paid by off-farm activities.

From the optimization conditions, we may state the following proposition:

Proposition 1: an increase in off-farm income will lead to a reduction in the use of farmland, therefore reducing deforestation pressure.

Proof: First we show that, given the complementarity between farm labor and farmland use, an increase (reduction) in farm labor implies in increasing (decreasing) farmland use.

From conditions (8), we observe that $q_{2}\left(l^{o n}, n\left(l^{o n}\right)\right)=0$. By applying the implicit function theorem, we have

$$
\frac{d(n)}{d\left(l^{o n}\right)}=-\frac{q_{21}\left(l^{o n}, n\left(l^{o n}\right)\right)}{q_{22}\left(l^{o n}, n\left(l^{o n}\right)\right.}>0
$$

In other words, an increase (reduction) in farm labor implies in increasing (decreasing) farmland use.

By taking the total differential of equation (9) while keeping the exogeneous variable $p$ constant, we have

$$
d\left(w^{o f f}\right)=p\left[q_{11}\left(l^{o n}, n\right) d\left(l^{o n}\right)+q_{12}\left(l^{o n}, n\right) \frac{d(n)}{d\left(l^{o n}\right)} d\left(l^{o n}\right)\right]
$$

Therefore, an increase in off-farm income implies a higher marginal productivity associated to farm activities, which is obtained by reducing $l^{o n}$ and $n$.

This result may be explained by the higher opportunity cost associated to farm labor when there is an increase in off-farm income $w^{o f f}$. Farmers will allocate less time to farm labor, thus reducing $l^{o n}$ and farmland use $n$. Since farm activities become less attractive vis-a-vis the off-farm labor market, there is a reduction in deforestation pressure.

\subsection{Introducing market failures: restricted access to off-farm la- bor markets}

In this section we show that rural households which face restricted access to off-farm labor markets may incur in inefficient decisions regarding farm labor and land use. Specifically, households which must attain a certain threshold level in agricultural production may 
choose farm labor and land use quantities above the optimal level, leading to more deforestation pressure.

Suppose that the rural household must attain a minimum production level $\bar{q}$. This can be the case of smallholders who should attain a certain subsistence level. In this case, the optimization problem is given by

$$
\begin{aligned}
\underset{l^{o n}, l^{o f f}, n}{\operatorname{Max}} & =U\left[p q\left(l^{o n}, n\right)+w^{o f f} l^{o f f}, T-l^{o n}-l^{o f f}, c\right] \\
& \text { such that }
\end{aligned}
$$

$$
\begin{gathered}
q\left(l^{o n}, n\right) \geq \bar{q} \\
n \leq N ; \\
l^{o n} \geq 0 \\
l^{o f f} \geq 0
\end{gathered}
$$

The first order conditions for the optimization program are the following:

$$
\begin{gathered}
U_{1(.)} w^{o f f}-U_{2(.)}=0 \\
U_{1(.)} p q_{1(.)}-U_{2(.)}=0 \\
-U_{1(.)} p q_{2(.)}+\mu^{q} q_{2(.)}+\mu^{n}=0 \\
\mu^{q}\left[\bar{q}-q\left(l^{o n}, n\right)=0, \mu^{q} \geq 0, c-q\left(l^{o n}, n\right) \leq 0\right. \\
\mu^{n}=0, \mu^{n} \geq 0
\end{gathered}
$$

where $\mu^{\mathrm{n}}$ and $\mu^{\mathrm{q}}$ are the Lagrangean multipliers associated to the land and production restrictions, respectively.

The analysis of the first order conditions allows us to establish proposition 2 .

Proposition 2: for rural households facing a binding production restriction

- farmers will use the total land area $N$.

- farmers will allocate labor and land quantities to rural activities above the optimal level, increasing deforestation pressure.

Proof: Consider a rural household facing a binding production constraint, i.e., producing the minimum quantity $\bar{q}$. In this case, we have $\mu^{\mathrm{q}}>0$. From expression (15), we may observe that if $\mu^{\mathrm{q}}>0, \mu^{\mathrm{n}}$ is also strictly positive. Therefore, if farmers produce the minimum quantity $\bar{q}$, they will use all available land $N$. This result implies that smallholders that produce for subsistence purposes or sharecroppers that should have a minimum production performance will have higher deforestation rates. 
Finally, from conditions (13) and (14), we may observe that households facing binding production restrictions may not be able to equalize the marginal returns of farm and off-farm labor,

$$
w^{o f f}=p q_{1(.)}+\mu^{q} \frac{q_{1}(.)}{U_{1}(.)}
$$

The off-farm labor price faced by constrained households is a shadow-price whose value lies below the market price $w^{o f f}$. For these constrained agents, the opportunity cost associated to farm labor is lower than the marginal return associated to off-farm activities $w^{\text {off }}$. Given the lower opportunity costs, the agents choose farm labor and land use quantities above the optimal level, leading to increasing deforestation pressure. In addition to that, households facing biding production restrictions will be less sensitive to an increase in off-farm revenues.

In the empirical application that follows, we assume that smallholders face binding production constraints. As mentioned in the introductory section, $18 \%$ of the establishments reported that more than $90 \%$ of their total production is destined to self-consumption. Production for subsistence purposes is particularly important in small farms with less than 5 hectares (Grisa et al., 2014). The Agriculture Census also provides some evidence that access to off-farm labor markets varies according to farmsize: while $32 \%$ of the rural establishments with less than 5 hectares declared to have received revenues from off-farm activities, this percentage reaches $52 \%$ among establishments with total area ranging from 100 to 500 ha, rising up to $61 \%$ among those establishments with more than 2,500 ha (IBGE, 2009).

\section{Empirical evidence}

From the theoretical model described in the previous section, we can derive the following testable hypotheses: (i) higher off-farm income is associated with a reduction in deforestation; and (ii) higher off-farm income provides less incentives for smallholders to reduce deforestation when compared to large ones, since smallholders have restricted access to off-farm labor markets.

To evaluate the hypotheses, we specify an econometric model. The model is estimated by using a two dimensional pseudo-panel method. The panel is composed by the 604 municipalities located in the Amazon region and classified according to 11 farm size categories. ${ }^{4}$ The size categories are the clusters in our pseudo-panel structure.

The econometric model has the following specification:

$$
D e f_{i j}=\alpha+\beta_{1} Y_{i j}^{o f f}+\beta_{2} T_{i j}+\beta_{3} X_{i j}+\beta_{4} N_{i j}+\beta_{5} Y_{i j}^{o f f} \times N_{i j}+\eta_{j}+\theta_{i}+\epsilon_{i j}
$$

\footnotetext{
${ }^{4}$ Size categories are defined by the following intervals: category 1) below 1 ha. ; category 2) from 1 to 5 ha.; category 3) from 5 to 10 ha.; category 4) from 10 to 20 ha.; category 5) from 20 to 50 ha.; category 6) from 50 to 100 ha.; category 7) from 100 to 200 ha.; category 8) from 200 to 500 ha.; category 9) from 500 to 1,000 ha.; category 10) from 1,000 to 10,000 ha.; category 11) above 10,000 ha.
} 
where index $i$ refers to municipality and index $j$ represents farm size category $(j=1, \ldots, 11)$. Variable $D e f_{i j}$ is the deforestation measure in agricultural establishments located in municipality $i$ belonging to size category $j, Y_{i j}^{o f f}$ is the relative off-farm income measure, $T$ is a vector which provides the proportional distribution of the establishments according to land ownership status (owner, sharecropper, land renter and squatter), $X_{i j}$ is a vector of socioeconomic characteristics that may affect deforestation decisions and $N_{i j}$ is total farmland. Variable $Y_{i j}^{o f f} \times N_{i j}$ is the cross product between off-farm income and farmsize. By introducing the cross-product term, we allow the marginal impact of off-farm wage on deforestation to vary across farm size. Such heterogeneity enable us to assess the hypothesis that smallholders are less sensible to off-farm income increases. Parameters $\alpha$, $\beta_{1}, \beta_{2}, \beta_{3}, \beta_{4}$ and $\beta_{5}$ are the regression coefficients to be estimated, $\eta_{j}$ and $\theta_{i}$ stand for the fixed effects regarding farm size categories and municipality, respectively, while $\epsilon_{i j}$ represents the idiosyncratic error which is assumed to follow the distribution $\epsilon_{i j} \sim \operatorname{iid}\left(0, \sigma_{\epsilon}^{2}\right)$.

Database was constructed from the Brazilian Agricultural Census 2006. Variable Defij corresponds to total deforested area divided by the number of establishments within each category. This normalization is intended to mitigate scale effects associated to different number of observations within each size category. So, one can interpret variable $D e f_{i j}$ as the average deforested area in the representative farm of category $j$ at municipality $i$. A similar procedure is applied to normalize all regression variables expressed in level. Relative off-farm income $Y_{i j}^{o f f}$ is expressed in terms of share, computed by dividing off-farm wage $^{5}$ by total revenue from both agricultural and off-farm activities. The proportion of establishments according to ownership status is computed by dividing the number of establishments belonging to a certain ownership category by the total number of establishments. Variable $N_{i j}$ refers to the farm area of the representative establishment within category $j$. We also include as an explanatory variable the average debt of the representative establishment within category $j$. Households' efforts to increase revenues to pay their debt could positively contribute to deforestation.

Estimation of equation (19) raises endogeneity concerns. In fact, deforestation and labor supply decisions are likely to be simultaneous. In order to account for the endogeneity of the relative off-farm income, we use the share of rural pension benefits relative to the total revenue of the establishment as an instrument. The Brazilian social security reform of 1991 implemented the widespread coverage of rural pensions: any rural male worker above 60 years old or female rural worker above 55 years is eligible for old-age benefits irrespective of the decision to retire and of previous contribution to the social security system. The minimum benefit paid to rural old-age beneficiaries is one minimum salary, and coverage includes rural workers who are not heads of households. As observed by Carvalho Filho (2008), because Brazilian rural beneficiaries are subject to neither earnings test nor requirement to retire, the decision to apply for a rural old-age benefit is not strategic. Therefore, it should be not correlated to the error term of the regression. In addition to that, the income-support effect provided by rural benefits may relax the biding production restriction (Delgado and Cardoso Jr, 2000). Therefore, one could expect a positive relationship between the relative off-farm income and the share of rural benefits. This

\footnotetext{
${ }^{5}$ The 2006 Agricultural Census reports several types of off-farm revenues: salaries received in off-farm activities, pensions, retirement benefits, donations, governmental transfers and others. In constructing our off-farm income variable, we consider only the off-farm wage component.
} 
Table 1: Descriptive statistics - average values according to size category

\begin{tabular}{|c|c|c|c|c|c|c|c|c|c|}
\hline $\begin{array}{c}\text { Farm size } \\
\text { (ha) }\end{array}$ & $\begin{array}{c}\text { Defor- } \\
\text { estation } \\
(\%)\end{array}$ & $\begin{array}{c}\text { Share of } \\
\text { off-farm } \\
\text { wage }(\%)\end{array}$ & $\begin{array}{c}\text { Land- } \\
\text { owners } \\
(\%)\end{array}$ & $\begin{array}{l}\text { Rent } \\
(\%)\end{array}$ & $\begin{array}{c}\text { Share- } \\
\text { cropping } \\
(\%)\end{array}$ & $\begin{array}{c}\text { Squatter } \\
(\%)\end{array}$ & $\begin{array}{l}\text { Debt } \\
(\mathrm{R} \$)\end{array}$ & $\begin{array}{c}\text { Farms } \\
\text { (number) }\end{array}$ & $\begin{array}{c}\text { Surface } \\
\text { (ha) }\end{array}$ \\
\hline Less than 1 & 91.5 & 40.5 & 65.5 & 7.1 & 9.7 & 17.8 & 914.05 & 183.20 & 0.34 \\
\hline 1 to 5 & 82.6 & 39.9 & 75.4 & 6.0 & 3.7 & 14.8 & 2913.62 & 142.17 & 2.31 \\
\hline 5 to 10 & 69.0 & 33.9 & 86.6 & 2.2 & 1.6 & 9.6 & 3807.16 & 56.24 & 6.46 \\
\hline 10 to 20 & 62.9 & 39.5 & 87.8 & 4.3 & 0.9 & 6.9 & 5226.95 & 85.45 & 13.10 \\
\hline 20 to 50 & 55.4 & 48.4 & 89.8 & 3.2 & 0.8 & 6.2 & 7412.36 & 206.97 & 31.34 \\
\hline 50 to 100 & 55.9 & 51.5 & 89.1 & 2.9 & 2.4 & 5.6 & 10532.59 & 155.08 & 66.02 \\
\hline 100 to 200 & 55.4 & 53.1 & 90.1 & 2.8 & 1.7 & 5.3 & 16905.31 & 90.67 & 126.78 \\
\hline 200 to 500 & 54.8 & 56.3 & 90.6 & 3.2 & 1.6 & 4.5 & 43283.15 & 51.53 & 290.93 \\
\hline 500 to 1000 & 53.8 & 42.2 & 92.5 & 3.2 & 1.0 & 3.3 & 80745.87 & 20.54 & 623.60 \\
\hline 1000 to 10000 & 50.4 & 43.2 & 95.7 & 2.2 & 0.7 & 1.4 & 311632.45 & 23.71 & 2188.72 \\
\hline More than 10000 & 46.7 & 5.2 & 94.1 & 3.6 & 0.2 & 2.1 & 389909.41 & 3.71 & 17561.72 \\
\hline
\end{tabular}

is confirmed by the first stage of our instrumental variable regressions (see Appendix A1). ${ }^{6}$

Table 1 presents the average of each variable according to size category. It can be noted that larger establishments tend to deforest a smaller proportion of total area and to present higher off-farm income. Ownership structure is also related to farm size: the proportion of landowners is higher in the larger establishment categories. Preliminary evidence on the negative relationship between off-farm income and deforestation is provided by the scatter diagrams in Appendix A2. In the majority of states within the Amazon region, one may find a negative linear trend between off-farm wage and deforestation, indicating that higher deforestation rates are associated with low levels of off-farm income.

Table 2 presents the econometric results. Regression specifications differ according to the control variables, the use of instrumental variables and the inclusion of the cross-product variable accounting for the heterogeneity of off-farm wage marginal impacts. Regression results provide empirical support for the first hypothesis derived from the theoretical model. Coefficients related to off-farm income present the expected negative sign and they are statistically significant in all specifications that do not account for heterogeneity in off-farm wage marginal impacts (specifications (1) to (4) and (7)). This negative relation suggests that higher relative off-farm wage vis-à-vis on-farm revenues may reduce deforestation, providing empirical support to our first hypothesis. According to the specification presented in columns (7), a $1 \%$ increase in relative off-farm income contribute to a reduction of $0.07 \%$ in deforestation. This result is in line with our argument that higher off-farm income corresponds to an increase in opportunity costs regarding farming activities, reducing the attractiveness of farming activities and therefore deforestation.

The introduction of the cross-product (equations (5), (6), (8) and (9)) allows us to assess how deforestation decisions react to off-farm revenue variation according to farm size categories. The off-farm wage elasticity computed from equation (8) is presented in Figure

\footnotetext{
${ }^{6}$ It should be remarked that our instrument is based on the income composition of the rural household, and not on income level. In this sense, the share of rural benefits should be only indirectly related to deforestation via labor supply decisions.
} 
Table 2: Econometric results

Dependent variable: deforestation level at representative farm

\begin{tabular}{|c|c|c|c|c|c|c|c|c|c|}
\hline Variables & $\begin{array}{l}(1) \\
\text { PLS }\end{array}$ & $\begin{array}{l}(2) \\
\text { PLS }\end{array}$ & $\begin{array}{c}(3) \\
\text { PLS }\end{array}$ & $\begin{array}{c}(4) \\
\text { PLS }\end{array}$ & $\begin{array}{c}(5) \\
\text { PLS }\end{array}$ & $\begin{array}{l}(6) \\
\text { PLS }\end{array}$ & $\begin{array}{c}(7) \\
\text { P2SLS }\end{array}$ & $\begin{array}{c}(8) \\
\text { P2SLS }\end{array}$ & $\begin{array}{c}(9) \\
\text { P2SLS }\end{array}$ \\
\hline intercept & $\begin{array}{c}3.554 \\
(0.000)\end{array}$ & $\begin{array}{c}3.519 \\
(0.000)\end{array}$ & $\begin{array}{c}3.389 \\
(0.000)\end{array}$ & $\begin{array}{l}-0.053 \\
(0.662)\end{array}$ & $\begin{array}{c}0.056 \\
(0.667)\end{array}$ & $\begin{array}{c}0.128 \\
(0.303)\end{array}$ & $\begin{array}{c}-0.260 \\
(0.039)\end{array}$ & $\begin{array}{c}0.169 \\
(0.251)\end{array}$ & $\begin{array}{c}0.296 \\
(0.043)\end{array}$ \\
\hline $\ln$ (off-farm wage share) & $\begin{array}{l}-0.040 \\
(0.000)\end{array}$ & $\begin{array}{l}-0.035 \\
(0.000)\end{array}$ & $\begin{array}{l}-0.026 \\
(0.000)\end{array}$ & $\begin{array}{l}-0.005 \\
(0.306)\end{array}$ & $\begin{array}{c}0.043 \\
(0.001)\end{array}$ & $\begin{array}{c}0.055 \\
(0.000)\end{array}$ & $\begin{array}{l}-0.071 \\
(0.000)\end{array}$ & $\begin{array}{l}0.096 \\
(0.002)\end{array}$ & $\begin{array}{c}0.094 \\
(0.007)\end{array}$ \\
\hline rent & & $\begin{array}{c}0.435 \\
(0.000)\end{array}$ & $\begin{array}{c}0.437 \\
(0.000)\end{array}$ & $\begin{array}{c}0.493 \\
(0.000)\end{array}$ & $\begin{array}{c}0.501 \\
(0.000)\end{array}$ & $\begin{array}{c}0.475 \\
(0.000)\end{array}$ & $\begin{array}{c}0.391 \\
(0.000)\end{array}$ & $\begin{array}{c}0.375 \\
(0.000)\end{array}$ & $\begin{array}{c}0.378 \\
(0.000)\end{array}$ \\
\hline sharecrop & & $\begin{array}{l}0.186 \\
(0.253)\end{array}$ & $\begin{array}{c}0.396 \\
(0.041)\end{array}$ & $\begin{array}{c}0.568 \\
(0.000)\end{array}$ & $\begin{array}{c}0.428 \\
(0.000)\end{array}$ & $\begin{array}{c}0.622 \\
(0.000)\end{array}$ & $\begin{array}{c}0.493 \\
(0.001)\end{array}$ & $\begin{array}{c}0.632 \\
(0.000)\end{array}$ & $\begin{array}{c}0.640 \\
(0.000)\end{array}$ \\
\hline squatter & & $\begin{array}{c}0.300 \\
(0.001)\end{array}$ & $\begin{array}{c}0.121 \\
(0.096)\end{array}$ & $\begin{array}{c}0.189 \\
(0.001)\end{array}$ & $\begin{array}{c}0.256 \\
(0.000)\end{array}$ & $\begin{array}{c}0.199 \\
(0.000)\end{array}$ & $\begin{array}{c}0.190 \\
(0.002)\end{array}$ & $\begin{array}{c}0.242 \\
(0.000)\end{array}$ & $\begin{array}{c}0.344 \\
(0.000)\end{array}$ \\
\hline $\ln ($ debt $)$ & & & $\begin{array}{c}0.025 \\
(0.024)\end{array}$ & $\begin{array}{l}0.023 \\
(0.007)\end{array}$ & & $\begin{array}{c}0.024 \\
(0.006)\end{array}$ & $\begin{array}{c}0.024 \\
(0.012)\end{array}$ & $\begin{array}{c}0.032 \\
(0.001)\end{array}$ & \\
\hline $\ln ($ farm size $)$ & & & & $\begin{array}{l}0.780 \\
(0.000)\end{array}$ & $\begin{array}{c}0.804 \\
(0.000)\end{array}$ & $\begin{array}{c}0.744 \\
(0.000)\end{array}$ & $\begin{array}{c}0.777 \\
(0.000)\end{array}$ & $\begin{array}{c}0.674 \\
(0.000)\end{array}$ & $\begin{array}{c}0.690 \\
(0.000)\end{array}$ \\
\hline $\begin{array}{l}\ln (\text { off-farm wage share }) \\
\times \ln (\text { farm size })\end{array}$ & & & & & $\begin{array}{l}-0.009 \\
(0.001)\end{array}$ & $\begin{array}{l}-0.012 \\
(0.000)\end{array}$ & & $\begin{array}{l}-0.034 \\
(0.000)\end{array}$ & $\begin{array}{l}-0.039 \\
(0.000)\end{array}$ \\
\hline Adjusted $R^{2}$ & 0.969 & 0.970 & 0.979 & 0.988 & 0.981 & 0.988 & 0.986 & 0.9 & 0.981 \\
\hline SSR & 291.63 & 286.58 & 150.71 & 87.03 & 175.78 & 85.58 & 69.67 & 70.79 & 113.58 \\
\hline Samp & 3119 & 3117 & 2669 & 2669 & 3117 & 2669 & 2326 & 2326 & 2559 \\
\hline$F$-test fixed effects & $\begin{array}{l}375.10 \\
(0.000)\end{array}$ & $\begin{array}{l}290.46 \\
(0.000)\end{array}$ & $\begin{array}{l}203.16 \\
(0.000)\end{array}$ & $\begin{array}{l}18.97 \\
(0.000)\end{array}$ & $\begin{array}{l}14.14 \\
(0.000)\end{array}$ & $\begin{array}{l}19.28 \\
(0.000)\end{array}$ & $\begin{array}{c}17.52 \\
(0.000)\end{array}$ & $\begin{array}{l}19.10 \\
(0.000)\end{array}$ & $\begin{array}{c}26.77 \\
(0.000)\end{array}$ \\
\hline Shea's partial $R^{2}$ & & & & & & & 0.132 & 0.137 & 0.145 \\
\hline
\end{tabular}

1. One can notice that smallholders are less responsive to the increase in the returns of off-farm activities than large ones, which is in line with our hypothesis of labor market imperfections regarding off-farm activities. In fact, for the first two size categories, an increase in off-farm revenues is associated to higher deforestation. From the third category on, an increase in off-farm revenues is associated to a reduction in the deforestation. The reduction is higher for large farms. One possible explanation for this pattern is the restricted access to off-farm activities faced by smallholders.

The influence of ownership status on deforestation patterns is assessed by using landowners as the reference category. Results show a positive relation between the proportion of squatters and deforestation. This can be explained by the precarious property rights conditions experienced by squatters. Land insecurity experienced by squatters may increase their discount rate, therefore increasing deforestation pressure (Araujo and AraujoBonjean, 1999). Land renters also tend to deforest more than landowners. This result may be explained by the fact that rented lands are the ones with highest agricultural potential. Finally, it should be remaked that the sign of the debt variable is positive, as expected.

\section{Conclusion and policy recommendations}

This article aimed at evaluating the determinants of Amazon deforestation, with particular emphasis on the role of off-farm income. We first presented a microeconomic model which relates off-farm income to deforestation patterns. We then specified and estimated an econometric model using data on the 2006 Brazilian Agricultural Census. 
Figure1. Marginal effect of off-farm wage according to size category

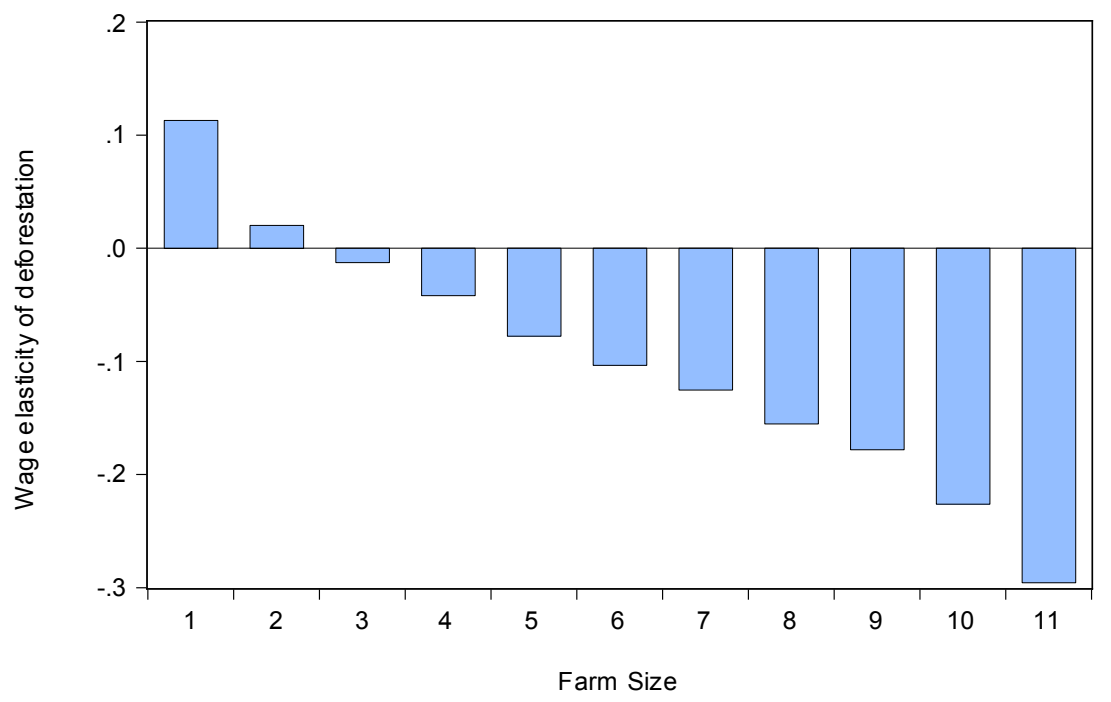

Our results suggest that an increase in off-farm income is likely to reduce deforestation. This finding may be explained by the fact that higher off-farm income increase the opportunity cost of farm labor, and so farmers allocate less time to agricultural activities and therefore deforestation pressure is reduced. In this sense, policymakers aiming at curbing deforestation may implement employment and income generation programs not directly related to agricultural activities. For example, policymakers may provide economic incentives for forest-related acivities. By making forestry activities economically more attractive, it raises the opportunity cost of agricultural activities, therefore reducing deforestation.

Results also show that smallholders are less responsive to the increase in the returns of off-farm activities than large ones, which is in line with our hypothesis of labor market imperfections regarding off-farm activities.

Regarding ownership status, results suggest that renters and squatters tend to deforest a larger extent of their establishment areas, when compared to landowners. On the other hand, results do not provide empirical support to the hypothesis that sharecroppers tend to deforest more due to labor market imperfections.

\section{References}

Andersen, L. And E. Reis (1997): "Deforestation, Development, and Government Policy in the Brazilian Amazon: An Econometric Analysis," Texto para discussão 513, IPEA.

Andrade, S., C. Palmer, And S. Di Falco (2013): "Dynamics of indirect land-use change: Empirical evidence from Brazil," Journal of Environmental Economics and Management, 65, 377-393. 
Angelsen, A. And D. Kaimowitz (1999): "Rethinking the Causes of Deforestation: Lessons from Economic Models," The World Bank Research Observer, 14, 73-98.

Araujo, C. And C. Araujo-Bonjean (1999): "Mesure de l'efficience économique des modes de faire valoir au Brésil," Canadian Journal of Agricultural Economics, 47, 191197.

Araujo, C., C. Araujo-Bonjean, J. Combes, P. Motel-Combes, and E. Reis (2009): "Property rights and deforestation in the Brazilian Amazon," Ecological Economics, 68, 2461-2468.

Barbier, E. And J. Burgess (2001): "The Economics of Tropical Deforestation," Journal of Economic Surveys, 15, 413-433.

Barona, E., N. Ramankutty, G. Hyman, and O. Coomes (2010): "The role of pasture and soybean in deforestation of the Brazilian Amazon," Environmental Research Letters, 5.

Bluffstone, R. (1995): "The Effect of Labor Market Performance on Deforestation in Developing Countries under Open Access: An Example from Rural Nepal," Journal of Environmental Economics and Management, 29, 42-63.

Carvalho Filho, I. (2008): "Old-age benefits and retirement decisions of rural elderly in Brazil," Journal of Development Economics, 86, 129-146.

Chomitz, K. And T. Thomas (2003): "Determinants of land use in Amazonia: a finescale spatial analysis," American Journal of Agricultural Economics, 85, 1016-1028.

Conte, L. And J. Ferreira Filho (2007): "Substituição de fatores produtivos na produção de soja no Brasil," Revista de Economia e Sociologia Rural, 45, 475-495.

Delgado, G. And J. CARdoso JR (2000): "Principais resultados da pesquisa domiciliar sobre a Previdência Rural na Região Sul do Brasil," Texto para Discussão 734, IPEA, Rio de Janeiro.

Ferraz, C. (2001): "Explaining Agricultural Expansion and Deforestation: Evidence from the Brazilian Amazon," Texto para Discussão 828, IPEA, Brasilia.

Gomes, M. And P. Rosado (2005): "Mudança na produtividade dos fatores de produção da cafeicultura nas principais regiões produtoras do Brasil," Revista de Economia e Sociologia Rural, 43, 633-655.

Grisa, C., S. Schneider, And M. Conterato (2014): "A produção para autoconsumo no Brasil: uma análise a partir do Censo Agropecuário 2006," in Aspectos multidimensionais da agricultura brasileira: diferentes visões do Censo Agropecuário 2006, ed. by S. Schneider and F. Ferreira, Brasilia: IPEA, chap. 6, 165-186.

Groom, B., P. Grosjean, A. Kontoleon, T. Swanson, and S. Zhang (2010): "Relaxing rural constraints: a win-win policy for poverty and environment in China?" Oxford Economic Papers, 62, 132-156.

IBGE (2009): Censo Agropecuário 2006: Brasil, grandes regiões e unidades da Federação, ISSN:0103-6157, Rio de Janeiro, ibge ed. 
Margulis, S. (2003): Causas do desmatamento da Amazônia Brasileira, ISBN: 85881192-10-1, Brasilia: Banco Mundial, $1^{\text {st }}$ ed.

Nepstad, D., B. Soares, E. Merry, A. Lima, P. Moutinho, J. Carter, M. Browman, A. Cattaneo, H. Rodrigues, and S. Schwartzman (2009): "The End of Deforestation in the Brazilian Amazon," Science, 326, 1350-1351.

Pfaff, A. (1999): "What drives deforestation in the Brazilian Amazon? Evidence from satellite and socioeconomic data," Journal of Environmental Economics and Management, 37, 26-43.

Reis, E. And F. Blanco (2000): "The Causes of Brazilian Amazon Deforestation," in World Forests : From Deforestation to Transition?, ed. by M. Paolo and H. Vanhanen, Dordrecht: Kluwer Academic Publishers.

Shively, G. And S. PAgiola (2004): "Agricultural intensification, local labor markets and deforestation in the Phillipines," Environment and Development Economics, 9, 241-266.

\section{Appendix}

Appendix A1: Instrumental variable regression - first stage results Dependent variable: $\ln$ (off-farm wage share)

\begin{tabular}{lccc}
\hline Variables & $\begin{array}{c}\text { Specification } \\
(7)\end{array}$ & $\begin{array}{c}\text { Specification } \\
(8)\end{array}$ & $\begin{array}{c}\text { Specification } \\
(9)\end{array}$ \\
\hline intercept & -0.670 & -0.704 & -0.570 \\
& $(0.118)$ & $(0.105)$ & $(0.073)$ \\
$\ln$ (retire share) & 0.511 & 0.498 & 0.434 \\
& $(0.000)$ & $(0.000)$ & $(0.000)$ \\
rent & -0.527 & -0.513 & -0.592 \\
& $(0.017)$ & $(0.022)$ & $(0.006)$ \\
sharecrop & -0.366 & -0.379 & -0.077 \\
& $(0.467)$ & $(0.456)$ & $(0.859)$ \\
squatter & -0.001 & 0.003 & 0.057 \\
& $(0.995)$ & $(0.989)$ & $(0.741)$ \\
$\ln ($ debt $)$ & 0.011 & 0.011 & \\
& $(0.708)$ & $(0.707)$ & \\
$\ln ($ farm size) & -0.148 & -0.141 & -0.159 \\
& $(0.065)$ & $(0.084)$ & $(0.030)$ \\
$\ln ($ retire share $)$ & & 0.003 & 0.014 \\
$\times \ln ($ farm size $)$ & & $(0.797)$ & $(0.145)$ \\
\hline Adjusted $R^{2}$ & 0.645 & 0.644 & 0.632 \\
SSR & 969.37 & 969.33 & 1161.56 \\
Sample & 2326 & 2326 & 2559 \\
\hline Note: $p$-value in parenthesis & &
\end{tabular}


Appendix A2. Scatter diagrams - off-farm wage share and deforestation share
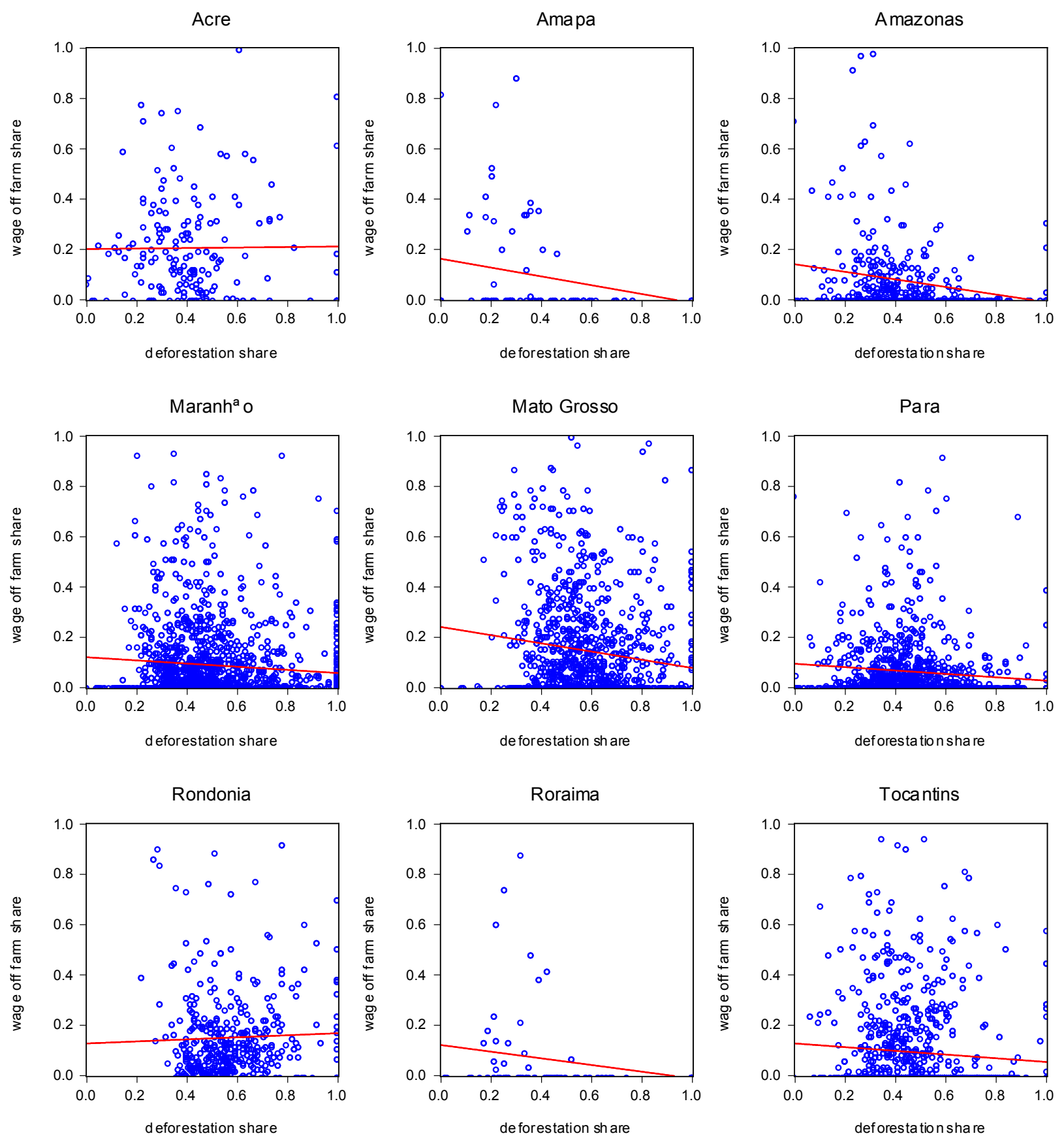